\title{
Peroxisome proliferator-activated receptor alpha: role in rodent liver cancer and species differences
}

\section{P R Holden and J D Tugwood ${ }^{\mathbf{1}}$}

\author{
Zeneca Central Toxicology Laboratory, Alderley Park, Macclesfield, SK10 4TJ, UK \\ ${ }^{1}$ Safety of Medicines Department, Zeneca Pharmaceuticals, Alderley Park, Macclesfield, SK10 4TG, UK
}

(Requests for offprints should be addressed to P R Holden)

\begin{abstract}
Peroxisome proliferators (PPs) are chemicals of industrial and pharmaceutical importance that elicit liver carcinogenesis by a non-genotoxic mechanism. One of the intriguing properties of PPs is that the pleiotropic effects of these compounds (including increased DNA synthesis and peroxisome proliferation) are seen in rats and mice only, but not humans. It is important to determine the risks to humans of environmental and therapeutic exposure to these compounds by understanding the mechanisms of non-genotoxic hepatocarcinogenesis in rodents. To understand this apparent lack of human susceptibility, attention has focused on the peroxisome proliferator-activated receptor alpha $(\operatorname{PPAR} \alpha)$, which appears to mediate the effects of PPs in rodents. It is also known to mediate the hypolipidaemic effects that fibrate drugs exert on humans with elevated plasma cholesterol and
\end{abstract}

triglyceride levels. Human PPARas share many functional characteristics with the rodent receptors, in that they can be transcriptionally activated by PPs and regulate specific gene expression. However, one key difference is that PPAR $\alpha$ is less abundant in human than in rodent liver, which has led to the suggestion that species differences result from quantitative differences in gene expression. In this review we describe the effects of PPs and what is known of the molecular mechanisms of action and species differences with respect to rodents and man. Attention will be given to differences in the amounts of PPAR $\alpha$ between species as well as the 'qualitative' aspects of PPAR $\alpha$-mediated gene regulation which might also explain the activation of some genes and not of others in human liver by PPs.

Fournal of Molecular Endocrinology (1999) 22, 1-8

\section{BACKGROUND}

Peroxisome proliferators (PPs) are a class of non-genotoxic carcinogens that cause liver tumours in rodents (Moody et al. 1991, Ashby et al. 1994). Included in this class are hypolipidaemic drugs, industrial plasticisers, herbicides and some leukotriene antagonists (Reddy \& Lalwani 1983, Marsman et al. 1988, Eacho et al. 1991). When administered to rats and mice, PPs cause a marked increase in the size and number of hepatocyte peroxisomes. Peroxisomes are subcellular organelles which perform a number of functions that include the $\beta$-oxidation of fatty acids and cholesterol metabolism. PPs also cause liver hypertrophy and hyperplasia in rodents, leading to the growth of hepatocellular carcinomas (Reddy et al. 1980, Kraupp-Grassl et al. 1991, Moody et al. 1991). There have been a number of explanations for the observed hepatocarcinogenicity in rodents. One suggestion was that PPs caused an increase in hydrogen peroxide by altering the activity of the peroxisomal hydrogen peroxide-producing enzymes leading to oxidative stress and DNA damage (Reddy \& Rao 1986, Rao \& Reddy 1991, Clayson et al. 1994). Subsequent data have suggested that PPs can perturb the mechanisms controlling hepatocyte growth and apoptosis. It has long been accepted that PP-induced DNA synthesis is likely to play a major role in their hepatocarcinogenicity (Ashby et al. 1994). In addition, PPs can suppress hepatocyte apoptosis, possibly preventing the 


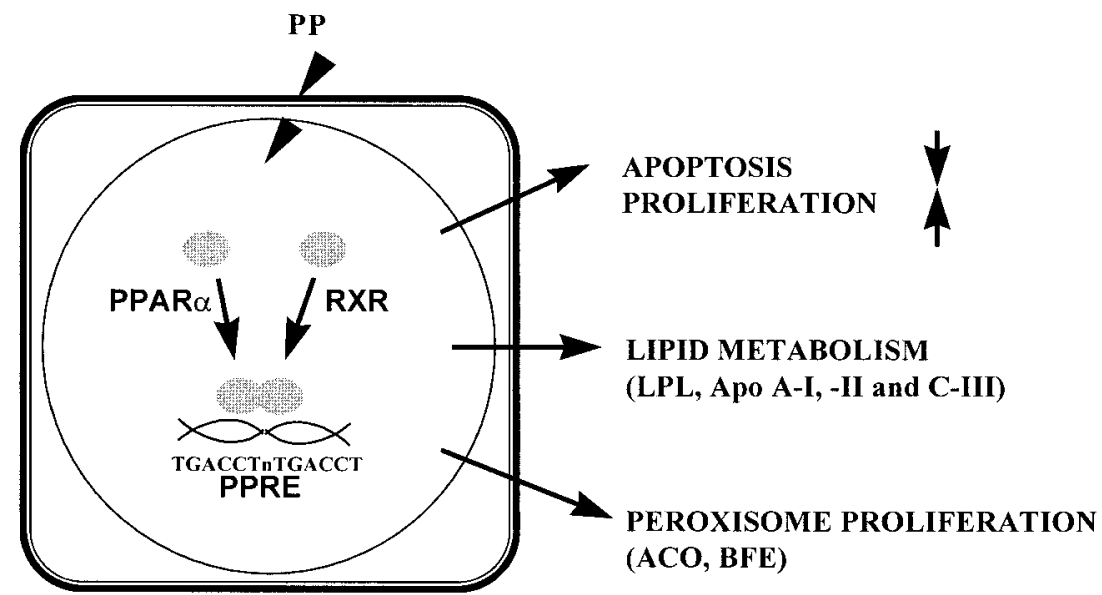

FIGURE 1. Proposed model of PP action. PPs enter the cell and cause heterodimerisation of PPAR $\alpha$ with RXR, which binds to the PPRE DNA element. The PPRE consists of a direct repeat of two copies of an TGACCT-like sequence separated by a single base (a DR-1 repeat) and has been identified in the promoters of genes such as ACO and LPL. Binding modulates transcription of target genes resulting in changes in peroxisome proliferation, lipid metabolism, growth and apoptosis.

removal of DNA-damaged cells (Bursch et al. 1984, Gerbracht et al. 1990, James \& Roberts 1996). The molecular mechanisms of these growth changes remain unclear despite recent evidence of PPinduced perturbation of growth and apoptotic signalling pathways (Rininger et al. 1997, Rokos \& Ledwith 1997, Holden et al. 1998).

A number of studies have shown that humans do not display the same range of PP-induced responses seen in rats and mice (Frick et al. 1987, Blaauboer et al. 1990). The guinea pig and non-human primates also appear unaffected by PPs (Foxworthy et al. 1990, Makowska et al.1992, Chinje et al.1994, Pacot et al. 1996). Establishing an explanation for species differences and an understanding of the risks to man from exposure to these chemicals has been a major focus for research. Published data over recent years have provided compelling evidence for a ligand-activated transcription factor, peroxisome proliferator-activated receptor alpha $(\operatorname{PPAR} \alpha)$, as a major mediator of PP action. This receptor has also provided some clues on why differences in response exist between species.

\section{PPAR $\alpha$ MEDIATES RESPONSES TO PPS}

It was suggested in 1988 that PPs might act like steroid and retinoid hormones, through a nuclear receptor (Evans 1988). Thus, PPAR was isolated following a screen for nuclear receptors of a mouse liver cDNA library (Issemann \& Green 1990). It was shown to be highly expressed in rat and mouse and activated by a number of PPs (Issemann \& Green 1990, Kliewer et al. 1994). The receptor was later designated PPAR $\alpha$, as it turned out to be the 'prototype' of a family of PPARs that now includes three other isoforms, $\beta, \gamma$ and $\delta$ (Dreyer et al. 1992, Schmidt et al. 1992, Kliewer et al. 1994) which have been cloned from a number of species (Gottlicher et al. 1992, Aperlo et al. 1995, Tugwood et al. 1998). PPAR $\alpha$ is expressed predominantly in rodent liver and kidney, which are known target tissues for PPs (Issemann \& Green 1990, Braissant et al. 1996, Lambe \& Tugwood 1996). Although receptor activation is a post-translational event, little is known about the activating ligand for PPAR $\alpha$. It has been shown to be activated by leukotriene B4 and the eicosaniod 8(S)-hydroxyeicosatetraenoic acid (Yu et al. 1995, Devchand et al. 1996) as well as a number of fibrate drugs and fatty acids (Forman et al. 1997, Kliewer et al. 1997).

In rodents, PPARa regulates transcription of a number of genes involved in both peroxisome proliferation and the $\beta$-oxidation of fatty acids by binding to a specific DNA regulatory element located in the upstream promoter region of these genes (Fig. 1). First it forms a heterodimer with another nuclear receptor, the retinoid $\mathrm{X}$ receptor (RXR) and then the heterodimer binds to the DNA element termed the peroxisome proliferator response element (PPRE). The PPRE consists of a direct repeat of two copies of an TGACCT-like sequence separated by a single base (a DR-1 repeat) and has been identified in the promoters of rat genes such as acyl CoA oxidase (ACO), bifunctional 
dehydrogenase/hydratase (BFE) and microsomal cytochrome P450IVA1 (Tugwood et al. 1992, Zhang et al. 1992, Bardot et al. 1993, Aldridge et al. 1995) (Fig. 1). PPAR $\alpha$ is also involved in modulating serum cholesterol levels, particularly high density lipoprotein cholesterol, in humans as well as rodents, through the regulation of target genes such as apolipoprotein (Apo) A-I, A-II and C-III (Schoonjans et al. 1996, Latruffe \& Vamecq 1997, Peters et al. 1997).

Perhaps the most compelling data implicating PPAR $\alpha$ in peroxisome proliferation and hepatocarcinogenicity come from studies of PPAR $\alpha$-null mice. Mice homozygous for a disrupted PPAR $\alpha$ gene showed no apparent gross phenotypic abnormalities either externally or internally (Lee et al. 1995). In addition these mice showed no hepatic enzyme induction, liver growth or peroxisome proliferation in response to the PPs WY-14,643 and clofibrate (Lee et al. 1995, Gonzalez 1997). Further studies have shown that basal levels of serum cholesterol, high density lipoprotein and hepatic Apo A-I increase, supporting a role for PPAR $\alpha$ in cholesterol regulation (Peters et al. 1997).

\section{SPECIES DIFFERENCES IN RESPONSE TO PPS}

PPs show a high degree of species specificity in their toxicity and carcinogenicity (Stringer 1992). The increase in growth and peroxisome proliferation seen in rat and mouse liver is not seen in guinea pigs, dogs, non-human primates and, more importantly, humans. In humans these findings have come from epidemiological studies with hypolipidaemic drugs (Hanefeld et al. 1983, Frick et al. 1987) and from in vitro experiments with human hepatocytes (Elcombe \& Styles 1989, Parzefall et al . 1991). However, these drugs do lower elevated plasma cholesterol levels by acting through genes such as Apo A-I, -II, C-III and also lipoprotein lipase (LPL). This would suggest that humans are responsive, at least in part, to the effects of PPs. These reports are supported by the finding that active PPAR $\alpha$ has been found in human and guinea pig liver (Sher et al. 1993, Mukherjee et al. 1994, Tugwood et al. 1998) and that genes such as Apo A-II and LPL contain a responsive PPRE (Vu-Dac et al. 1995, Schoonjans et al. 1996). Since humans clearly respond to PPs, but differently from rodents, it is difficult to determine the risk to humans from PPs based on rodent data. There are several explanations for these observed differences in response between rodents and humans. There may be a difference in the relative amounts of active
PPAR $\alpha$ receptor mRNA required to modulate growth, peroxisome proliferation and cholesterol metabolism, suggesting a quantitative difference between species. Alternatively, there may be a qualitative difference between species, in that human hepatocytes may lack an activator or have an active repressor of PPAR $\alpha$ function, or that target genes (for DNA synthesis, peroxisome proliferation) contain altered or unresponsive PPRE sequences.

\section{QUANTITATIVE DIFFERENCES BETWEEN SPECIES}

It has been suggested previously that the relative amounts of PPAR $\alpha$ mRNA differ between responsive and non-responsive species since lower transcript levels are detected in human and guinea pig liver compared with rat and mouse (Tugwood et al. 1996, 1998, Auboeuf et al. 1997, Palmer et al. 1998). On average it is estimated that human hepatocytes express PPAR $\alpha$ at $5-10 \%$ of the levels found in rodent hepatocytes. However, despite the low levels of mRNA, humans are still able to respond to PPs by changes in serum lipid levels. Therefore there may be sufficient amounts of PPAR $\alpha$ mRNA in human and guinea pig liver to maintain lipid homeostasis but not growth and peroxisome proliferation. A model for this is illustrated in Fig. 2 , showing the different activation thresholds required to drive the peroxisomal $\left(\mathrm{T}_{\mathrm{p}}\right)$ and lipid homeostasis $\left(\mathrm{T}_{\mathrm{L}}\right)$ genes. It would be useful to test this hypothesis by increasing experimentally the levels of guinea pig or human PPAR $\alpha$ mRNA in respective tissues. It would follow from this model that those genes that require a lower threshold of PPAR $\alpha$ mRNA would also respond to lower concentrations of the ligand. However, evidence shows that genes associated with the peroxisome proliferation response in rodents are very sensitive to low levels of PPs (Wada et al. 1992, Berthou et al. 1995).

\section{QUALITATIVE DIFFERENCES BETWEEN SPECIES}

There may be a qualitative difference between species in response to PPs with respect to growth and peroxisome proliferation. For example, it has been suggested that the human hepatocyte may lack a transcriptional activator or conversely may contain a transcriptional inhibitor. A number of co-activators have been described that interact with PPAR/RXR heterodimers to facilitate transcriptional activation. These include the steroid receptor 


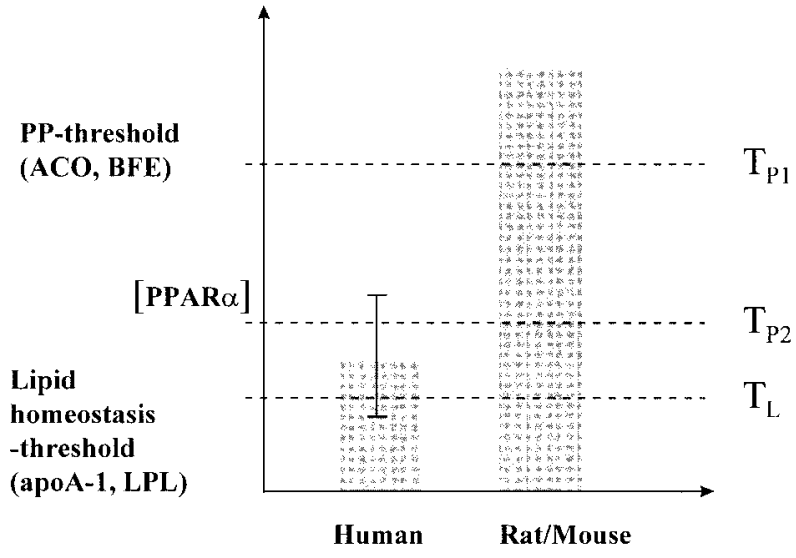

FIGURE 2. Schematic representation of relative PPAR $\alpha$ abundance in rodent and human livers. In rat and mouse, PPAR $\alpha$ is present at sufficiently high levels to exceed theoretical thresholds both for 'lipid homeostasis' gene activation $\left(\mathrm{T}_{\mathrm{L}}\right)$, and for 'peroxisome proliferation' gene activation $\left(\mathrm{T}_{\mathrm{P} 1}\right)$. Human livers contain lower amounts of PPAR $\alpha$, and so can regulate only the lipid homeostasis pathway. However, since there is considerable inter-individual variation in PPAR $\alpha$ expression in humans, a small proportion of individuals may lie below $\mathrm{T}_{\mathrm{L}}$ and be unresponsive to fibrate therapy for hyperlipidaemia (depicted by the error bar intersecting with $\mathrm{T}_{\mathrm{L}}$ ). Conversely, if the 'peroxisome proliferation' activation threshold is lower $\left(\mathrm{T}_{\mathrm{P} 2}\right)$, some individuals may show rodent-like toxic responses to PPs (depicted by the error bar intersecting with $\mathrm{T}_{\mathrm{P} 2}$ ).

co-activator 1 (SRC-1) (Kamei et al. 1996) and the integrator protein p300 (Dowell et al. 1997). Whether these proteins are involved in species differences is unknown. It has also been shown that the PPAR $\alpha /$ RXR heterodimer can behave as either a positive or negative regulatory factor in the same cell. The receptor can activate LPL by binding to its PPRE (Schoonjans et al. 1996) and inhibit Apo $\mathrm{C}-\mathrm{III}$ by displacing the positive regulator $\mathrm{HNF}-4$ (Hertz et al. 1995). Therefore, in the same cell, PPAR $\alpha / R X R$ could behave as either a positive or negative regulatory factor, depending on the structure of the gene promoters and the other proteins that interact with them. Also PPAR $\alpha /$ RXR has been shown to interact with the constitutive factors AP-1 (Sakai et al. 1995) and SP-1 (Krey et al. 1995). Some of the factors that potentially regulate the function of $\mathrm{PPAR} \alpha / \mathrm{RXR}$, either by protein-protein interactions or by competition for DNA binding, are depicted in Fig. 3. In rodents, other transcription factors can modulate the effects of PPAR $\alpha /$ RXR depending on the promoter context. The hepatic factors COUP-TF1 and HNF-4 recognise direct repeat elements very similar to PPREs and both can influence the regulation of $\mathrm{ACO}$ and BFE (Chu et al. 1995). More recently, the thyroid hormone receptor $\mathrm{TR} \alpha$ (Miyamoto et al. 1997) and the nuclear orphan receptor TAK1 (Yan et al. 1998) have been shown to repress the activity of PPAR/RXR by competitive binding to a PPRE-like element.

Qualitative differences might exist within the PPAR $\alpha$ gene itself. There are two published full length sequences of the human PPAR $\alpha$ gene that differ at two amino acid positions (Sher et al. 1993, Mukherjee et al. 1994). Both cognates are able to bind DNA and are responsive to PPs. Following a

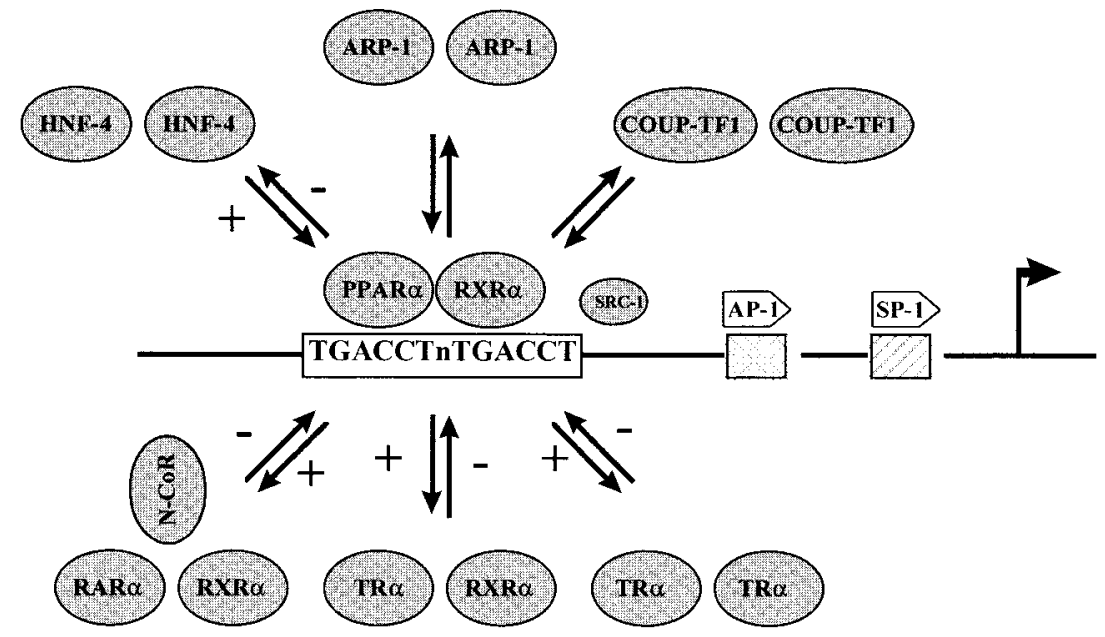

FIGURE 3. Regulation of PPAR $\alpha$ function by other nuclear factors. The PPAR $\alpha / R X R$ heterodimer is shown binding to a PPRE direct repeat sequence, and potential interactions with other homo- or heterodimeric nuclear proteins are depicted by arrows (see text for details). The constitutive factors AP-1 and SP-1 are also shown, together with the co-factors N-CoR and SRC-1 that interact with nuclear receptors. 
screen of human liver PPAR $\alpha$ cDNAs, another human PPARa has been isolated that has four amino acid differences from the wild-type sequence. Although this receptor was able to bind to a PPRE it could not be activated by a number of PPs (Myers et al. 1997) and could also act as a dominantnegative repressor of PPAR $\alpha$-mediated gene expression (Roberts et al. 1998). Recently another human mutant PPAR $\alpha$ has been cloned that lacks exon 6 as a result of alternate RNA splicing (Palmer et al. 1998). How and if these mutants act as dominantnegative repressors of peroxisomal and/or lipid homeostasis gene expression is unknown.

Finally, evidence suggests that PPREs may be altered or even absent in certain target genes. The PPRE for the human ACO, the first and ratelimiting enzyme of the peroxisomal $\beta$-oxidation system, has been cloned and sequenced (Varanasi et al. 1996). Located at -1918 to $-1906 \mathrm{bp}$ upstream of the transcription initiation site, this human sequence has several differences from the rat ACO PPRE. However, it was found to bind directly to PPAR/RXR and was responsive to a number of PPs in a reporter gene assay suggesting that this 'qualitative' sequence change is not a complete explanation for species differences. However, polymorphisms may exist in PPRE sequences among the human population.

\section{CONCLUSIONS}

The extensive information that has accumulated on the mechanism of PP action in rodents, and the responses of humans to these compounds, has yet to provide a definitive explanation for species differences in the effects of PPs. However, since its discovery, PPAR $\alpha$ has been shown to be an essential mediator of PP-induced responses in rodents and humans. The receptor is abundant in tissues that show the physiological changes associated with PPs and can be activated by a large number of PPs in in vitro assays. Perhaps the most convincing demonstration of PPAR $\alpha$ involvement in peroxisome proliferation, growth and lipid homeostasis comes from the PPAR $\alpha$-null mouse. The possibility that PPAR $\alpha$ holds the key to species differences is still a plausible premise irrespective of whether the quantity or the quality of the receptor is more relevant. In fact, the most likely explanation is that both qualitative and quantitative factors are important to human and rodent responses to PPs. While it may be tempting to conclude that a lack of induction of certain classes of genes in humans is due solely to reduced PPARa levels, there is a considerable weight of evidence to suggest this is an over-simplification. Clearly, there are a number of proteins, including other nuclear receptors, that are potent regulators of PPAR $\alpha$ function in the liver. The relative abundance of hepatic factors including PPAR $\alpha$, and the structures of gene promoters with which these factors interact, are critical to the quality and quantity of PP-mediated gene regulation.

Future work may reveal whether there are positive- or negative-acting nuclear factors that may interact with PPAR $\alpha$. In addition, there may be polymorphisms in humans in both the PPRE and PPAR $\alpha$ sequence. This may relate to the apparent differential responses of some human individuals to hypolipidaemic drugs. Studies are in progress to introduce the human PPAR $\alpha$ into PPAR $\alpha$-null mice by gene replacement experiments, generating transgenic animals with different levels of the receptor (Gonzalez 1997, and F Gonzalez, personal communication). Finally, it is unlikely that a single receptor alone will elicit such a complex pleiotropic response but likely, rather, that other mediators are required for the changes in growth, lipid perturbation and peroxisome proliferation. Genes associated with cell survival and proliferation, such as tumour necrosis factor alpha, are under investigation as potential candidates. This cytokine has received a great deal of interest of late as it can both suppress apoptosis and induce DNA synthesis in a manner similar to PPs (Bojes et al. 1997, Rolfe et al. 1997, P R Holden, N H James, R Brindle \& R A Roberts, unpublished observations).

\section{REFERENCES}

Aldridge TC, Tugwood JD \& Green S 1995 Identification and characterization of DNA elements implicated in the regulation of CYP4A1 transcription. Biochemical fournal 306 473-479.

Aperlo C, Pognonec P, Saladin R, Auwerx J \& Boulukos KE 1995 cDNA cloning and characterization of the transcriptional activities of the hamster peroxisome proliferator-activated receptor haPPAR gamma. Gene 162 297-302.

Ashby J, Brady A, Elcombe CR, Elliott BM, Ishmael J, Odum J, Tugwood JD, Kettle S \& Purchase IFH 1994 Mechanistically-based human hazard assessment of peroxisome proliferator-induced hepatocarcinogenesis. Human and Experimental Toxicology 13 S1-S117.

Auboeuf D, Rieusset J, Fajas L, Vallier P, Frering V, Riou JP, Staels B, Auwerx J, Laville M \& Vidal H 1997 Tissue distribution and quantification of the expression of mRNAs of peroxisome proliferator-activated receptors and liver $\mathrm{X}$ receptor-alpha in humans: no alteration in adipose tissue of obese and NIDDM patients. Diabetes 46 1319-1327.

Bardot O, Aldridge TC, Latruffe N \& Green S 1993 PPAR-RXR heterodimer activates a peroxisome proliferator response element upstream of the bifunctional enzyme gene. Biochemical and Biophysical Research Communications 192 $37-45$. 
Berthou L, Saladin R, Yaqoob P, Branellec D, Calder P, Fruchart J-C, Denèfle P, Auwerx J \& Staels B 1995 Regulation of rat liver apolipoprotein A-I and acyl-coenzyme A oxidase gene expression by fibrates and dietary fatty acids. European Fournal of Biochemistry 232 179-187.

Blaauboer BJ, van Holsteijn CW, Bleumink R, Mennes WC, van Pelt FN, Yap SH, van Pelt JF, van Iersel AA, Timmerman A \& Schmid BP 1990 The effect of beclobric acid and clofibric acid on peroxisomal beta-oxidation and peroxisome proliferation in primary cultures of rat, monkey and human hepatocytes. Biochemical Pharmacology $\mathbf{4 0}$ 521-528.

Bojes HK, Germolec DR, Simeonova P, Bruccoleri A, Schoonhoven R, Luster MI \& Thurman RG 1997 Antibodies to tumor necrosis factor alpha prevent increases in cell replication in liver due to the potent peroxisome proliferator, WY-14,643. Carcinogenesis 18 669-674.

Braissant O, Foufelle F, Scotto C, Dauca M \& Wahli W 1996 Differential expression of peroxisome proliferator-activated receptors (PPARs): tissue distribution of PPAR-alpha, -beta, and -gamma in the adult rat. Endocrinology 137 354-366.

Bursch W, Lauer B, Timmermann-Trosiener I, Barthel G, Schuppler J \& Schulte-Hermann R 1984 Controlled death (apoptosis) of normal and putative preneoplastic cells in rat liver following withdrawal of tumor promoters. Carcinogenesis 5 453-458.

Chinje E, Kentish P, Jarnot B, George M \& Gibson G 1994 Induction of the CYP4A subfamily by perfluorodecanoic acid: the rat and the guinea pig as susceptible and non-susceptible species. Toxicology Letters 71 69-75.

Chu R, Lin Y, Rao MS \& Reddy JK 1995 Cooperative formation of higher order peroxisome proliferator-activated receptor and retinoid $\mathrm{X}$ receptor complexes on the peroxisome proliferator responsive element of the rat hydratase-dehydrogenase gene. Fournal of Biological Chemistry $27029636-29639$.

Clayson DB, Mehta R \& Iverson F 1994 International Commission for Protection Against Environmental Mutagens and Carcinogens. Oxidative DNA damage - the effects of certain genotoxic and operationally non-genotoxic carcinogens. Mutation Research 317 25-42.

Devchand PR, Keller H, Peters JM, Vazquez M, Gonzalez FJ \& Wahli W 1996 The PPAR $\alpha$-leukotriene B4 pathway to inflammation control. Nature 384 39-43.

Dowell P, Ishmael JE, Avram D, Peterson VJ, Nevrivy DJ \& Leid M 1997 p300 functions as a coactivator for the peroxisome proliferator-activated receptor alpha. Fournal of Biological Chemistry 272 33435-33443.

Dreyer C, Krey G, Keller H, Givel F, Helftenbein G \& Wahli W 1992 Control of the peroxisomal beta-oxidation pathway by a novel family of nuclear hormone receptors. Cell 68 879-887.

Eacho PI, Lanier TC \& Brodhecker CA 1991 Hepatocellular DNA synthesis in rats given peroxisome proliferating reagents: comparison of Wyeth-14,643 to clofibric acid, nafenopin and LY171883 in rats. Carcinogenesis 12 $1557-1561$

Elcombe CR \& Styles JA 1989 Species differences in peroxisome proliferation. Toxicology 963 .

Evans RM 1988 The steroid and thyroid hormone receptor superfamily. Science 240 889-895.

Forman BM, Chen J \& Evans RM 1997 Hypolipidemic drugs, polyunsaturated fatty acids, and eicosanoids are ligands for peroxisome proliferator-activated receptors alpha and delta. Proceedings of the National Academy of Sciences of the USA $944312-4317$.
Foxworthy PS, White SL, Hoover DM \& Eacho PI 1990 Effect of ciprofibrate, bezafibrate, and LY171883 on peroxisomal beta-oxidation in cultured rat, dog, and rhesus monkey hepatocytes. Toxicology and Applied Pharmacology 104 386-394.

Frick MH, Elo O, Haapa K, Heinonen OP, Heinsalmi P, Helo P, Huttunen JK, Kaitaniemi P, Koskinen P \& Manninen V 1987 Helsinki Heart Study: primary-prevention trial with gemfibrozil in middle-aged men with dyslipidemia. Safety of treatment, changes in risk factors, and incidence of coronary heart disease. New England Fournal of Medicine 317 $1237-1245$.

Gerbracht U, Bursch W, Kraus P, Putz B, Reinacher M, Timmermann-Trosiener I \& Schulte-Hermann R 1990 Effects of hypolipidemic drugs nafenopin and clofibrate on phenotypic expression and cell death (apoptosis) in altered foci of rat liver. Carcinogenesis 11 617-624.

Gonzalez F 1997 The role of peroxisome proliferator activated receptor $\alpha$ in peroxisome proliferation, physiological homeostasis, and chemical carcinogenesis. In Dietary Fat and Cancer, pp 109-125. Eds Association for International Cancer Research. New York: Plenum Press.

Gottlicher M, Widmark E, Li Q \& Gustafsson JA 1992 Fatty acids activate a chimera of the clofibric acid-activated receptor and the glucocorticoid receptor. Proceedings of the National Academy of Sciences of the USA 89 4653-4657.

Hanefeld M, Kemmer C \& Kadner E 1983 Relationship between morphological changes and lipid-lowering action of p-chlorphenoxyisobutyric acid (CPIB) on hepatic mitochondria and peroxisomes in man. Atherosclerosis $\mathbf{4 6}$ 239-246.

Hertz R, Bishara-Shieban J \& Bar-Tana J 1995 Mode of action of peroxisome proliferators as hypolipidemic drugs. Fournal of Biological Chemistry 270 13470-13475.

Holden PR, Odum J, Soames AR, Foster JR, Elcombe CR \& Tugwood JD 1998 Immediate early gene expression during regenerative and mitogen-induced liver growth in the rat. Fournal of Biochemistry and Molecular Toxicology 12 79-85.

Issemann I \& Green S 1990 Activation of a member of the steroid hormone receptor superfamily by peroxisome proliferators. Nature 347 645-649.

James NH \& Roberts RA 1996 Species differences in response to peroxisome proliferators correlate in vitro with induction of DNA synthesis rather than with suppression of apoptosis. Carcinogenesis 17 1623-1632.

Kamei Y, Xu L, Heinzel T, Torchia J, Kurokawa R, Gloss B, Lin S-C, Heyman R, Rose D, Glass C \& Rosenfeld M 1996 A CBP integrator complex mediates transcriptional activation and AP-1 inhibition by nuclear receptors. Cell 85 1-12.

Kliewer SA, Forman BM, Blumberg B, Ong ES, Borgmeyer U, Mangelsdorf DJ, Umesono K \& Evans RM 1994 Differential expression and activation of a family of murine peroxisome proliferator-activated receptors. Proceedings of the National Academy of Sciences of the USA 91 7355-7359.

Kliewer SA, Sundseth SS, Jones SA, Brown PJ, Wisely GB, Koble CS, Devchand P, Wahli W, Willson TM, Lenhard JM \& Lehmann JM 1997 Fatty acids and eicosanoids regulate gene expression through direct interactions with peroxisome proliferator-activated receptors alpha and gamma. Proceedings of the National Academy of Sciences of the USA 94 4318-4323.

Kraupp-Grassl D, Huber W, Taper H \& Schulte-Hermann R 1991 Increased susceptibility of aged rats to hepatocarcinogenesis by the peroxisome proliferator nafenopin and the possible involvement of altered liver foci occurring spontaneously. Cancer Research 51 666-671.

Krey G, Mahfoudi A \& Wahli W 1995 Functional interactions of peroxisome proliferator activated receptor, retinoid-X 
receptor, and $\mathrm{Sp} 1$ in the transcriptional regulation of the acyl-coenzyme-A oxidase promoter. Molecular Endocrinology 9 219-231.

Lambe KG \& Tugwood JD 1996 A human peroxisomeproliferator-activated receptor-gamma is activated by inducers of adipogenesis, including thiazolidinedione drugs. European Fournal of Biochemistry 239 1-7.

Latruffe N \& Vamecq J 1997 Peroxisome proliferators and peroxisome proliferator activated receptors (PPARs) as regulators of lipid metabolism. Biochimie 79 81-94.

Lee SST, Pineau T, Drago J, Lee EJ, Owens JW, Kroetz DL, Fernandez-Salguero PM, Westphal H \& Gonzalez FJ 1995 Targeted disruption of the $\alpha$ isoform of the peroxisome proliferator-activated receptor gene in mice results in abolishment of the pleiotropic effects of peroxisome proliferators. Molecular and Cellular Biology 15 3012-3022.

Makowska JM, Gibson GG \& Bonner FW 1992 Species differences in ciprofibrate induction of hepatic cytochrome P450 4A1 and peroxisome proliferation. Fournal of Biochemical Toxicology 7 183-191.

Marsman DS, Cattley RC, Conway JG \& Popp JA 1988 Relationship of hepatic peroxisome proliferation and replicative DNA synthesis to the hepatocarcinogenicity of the peroxisome proliferators di(2-ethylhexyl)phthalate and [4-chloro-6-(2,3-xylidino)-2-pyrimidinylthio]acetic acid (Wy-14,643) in rats. Cancer Research 48 6739-6744.

Miyamoto T, Kaneko A, Kakizawa T, Yajima H, Kamijo K, Sekine R, Hiramatsu K, Nishii Y, Hashimoto T \& Hashizumi K 1997 Inhibition of peroxisome proliferator signaling pathways by thyroid hormone receptor. Fournal of Biological Chemistry 272 7752-7758.

Moody DE, Reddy JK, Lake BG, Popp JA \& Reese DH 1991 Peroxisome proliferation and non-genotoxic carcinogenesis: Commentary on a symposium. Fundamental and Applied Toxicology 6 233-248.

Mukherjee R, Jow L, Noonan D \& McDonnell DP 1994 Human and rat peroxisome proliferator activated receptors (PPARs) demonstrate similar tissue distribution but different responsiveness to PPAR activators. Fournal of Steroid Biochemistry and Molecular Biology 51 157-166.

Myers KA, Lambe K, Aldridge TC, Macdonald N \& Tugwood JD 1997 Amino acids in both the DNA binding and ligand binding domains influence the transcriptional activity of the human peroxisome proliferator activated receptor alpha. Biochemical and Biophysical Research Communications 239 522-526.

Pacot C, Petit M, Rollin M, Behechti N, Moisant M, Deslex P, Althoff J, Lhuguenot JC \& Latruffe N 1996 Difference between guinea pig and rat in the liver peroxisomal response to equivalent plasmatic level of ciprofibrate. Archives of Biochemistry and Biophysics 327 181-188.

Palmer CN, Hsu MH, Griffin KJ, Raucy JL \& Johnson EF 1998 Peroxisome proliferator activated receptor-alpha expression in human liver. Molecular Pharmacology 53 14-22.

Parzefall W, Erber E, Sedivy R \& Schulte-Hermann R 1991 Testing for induction of DNA synthesis in human hepatocyte primary cultures by rat liver tumor promoters. Cancer Research 51 1143-1147.

Peters JM, Hennuyer N, Staels B, Fruchart JC, Fievet C, Gonzalez FJ \& Auwerx J 1997 Alterations in lipoprotein metabolism in peroxisome proliferator-activated receptor alpha-deficient mice. Fournal of Biological Chemistry 272 27307-27312.

Rao MS \& Reddy JK 1991 An overview of peroxisome-induced hepatocarcinogenesis. Environmental Health Perspectives 93 205-209.

Reddy JK \& Lalwani ND 1983 Carcinogenesis by hepatic peroxisome proliferators. Evaluation of the risk of hepatocarcinogenic drugs and industrial plasticizers to humans. Critical Reviews in Toxicology 12 1-58.

Reddy JK \& Rao MS 1986 Peroxisome proliferators and cancer: mechanisms and implications. Trends in Pharmacological Sciences 7 438-443.

Reddy JK, Azarnoff DL \& Hignite CE 1980 Hypolipidemic hepatic peroxisome proliferators form a novel class of chemical carcinogens. Nature 283 397-398.

Rininger JA, Goldsworthy TL \& Babish JG 1997 Time-course comparison of cell cycle protein expression following partial hepatectomy and $\mathrm{Wy}-14,643$-induced hepatic proliferation in F344 rats. Carcinogenesis 18 935-941.

Roberts RA, James NH, Woodyatt NJ, Macdonald N \& Tugwood JD 1998 Evidence for the suppression of apoptosis by the peroxisome proliferator activated receptor alpha (PPAR alpha). Carcinogenesis 19 43-48.

Rokos CL \& Ledwith BJ 1997 Peroxisome proliferators activate extracellular signal-regulated kinases in immortalized mouse liver cells. Fournal of Biological Chemistry 272 13452-13457.

Rolfe M, James NH \& Roberts RA 1997 Tumour necrosis factor $\alpha(\mathrm{TNF}-\alpha)$ suppresses apoptosis and induces DNA synthesis in rodent hepatocytes: a mediator of the hepatocarcinogenicity of peroxisome proliferators? Carcinogenesis 18 2277-2280.

Sakai M, Matsushima-Hibiya Y, Nishizawa M \& Nishi S 1995 Suppression of rat glutathione transferase $\mathrm{P}$ expression by peroxisome proliferators: interaction between Jun and peroxisome proliferator-activated receptor alpha. Cancer Research 55 5370-5376.

Schmidt A, Endo N, Rutledge SJ, Vogel R, Shinar D \& Rodan GA 1992 Identification of a new member of the steroid hormone receptor superfamily that is activated by a peroxisome proliferator and fatty acids. Molecular Endocrinology 6 1634-1641.

Schoonjans K, Peinado-Onsurbe J, Lefebvre A-M, Heyman RA, Briggs M, Deeb S, Staels B \& Auwerx J 1996 PPAR-alpha and PPAR-gamma activators direct a distinct tissue-specific transcriptional response via a PPRE in the lipoprotein lipase gene. EMBO fournal 15 5336-5348.

Sher T, Yi H-F, McBride OW \& Gonzalez FJ 1993 cDNA cloning, chromosomal mapping, and functional characterisation of the human peroxisome proliferator activated receptor. Biochemistry 32 5598-5604.

Stringer DA 1992 European Centre for Ecotoxicology and Toxicology of Chemicals Monograph No 17: Hepatic Peroxisome Proliferation. Brussels: ECETOC.

Tugwood JD, Issemann I, Anderson RG, Bundell KR, McPheat WL \& Green S 1992 The mouse peroxisome proliferator activated receptor recognizes a response element in the $5^{\prime}$ flanking region of the rat acyl CoA oxidase gene. EMBO Fournal 11 433-439.

Tugwood JD, Aldridge TC, Lambe KG, Macdonald N and Woodyatt NJ 1996 Peroxisome proliferator-activated receptors: structures and function. Annals of the New York Academy of Sciences 804 252-265.

Tugwood JD, Holden PR, James NH, Prince RA \& Roberts RA 1998 A peroxisome proliferator-activated receptor-alpha (PPARalpha) cDNA cloned from guinea-pig liver encodes a protein with similar properties to the mouse PPARalpha: implications for species differences in responses to peroxisome proliferators. Archives of Toxicology $\mathbf{7 2}$ 169-177.

Varanasi U, Chu R, Huang Q, Castellon R, Yeldandi AV \& Reddy JK 1996 Identification of a peroxisome proliferatorresponsive element upstream of the human peroxisomal fatty acyl coenzyme A oxidase gene. Fournal of Biological Chemistry 271 2147-2155. 
Vu-Dac N, Schoonjans K, Kosykh V, Dallongeville J, Fruchart JC, Staels B, Auwerx J 1995 Fibrates increase human apolipoprotein A-II expression through activation of the peroxisome proliferator-activated receptor. Fournal of Clinical Investigation 96 741-750.

Wada N, Marsman DS \& Popp JA 1992 Dose-related effects of the hepatocarcinogen, Wy-14,643, on peroxisomes and cell replication. Fundamental and Applied Toxicology 18 149-154.

Yan ZH, Karam WG, Staudinger JL, Medvedev A, Ghanayem BI \& Jetten AM 1998 Regulation of peroxisome proliferator-activated receptor alpha-induced transactivation by the nuclear orphan receptor TAK1/TR4. Fournal of Biological Chemistry 273 10948-10957.
Yu K, Bayano W, Kallen CB, Harding HP, Ravera CP, McMahon G, Brown M \& Lazar MA 1995 Differential activation of peroxisome proliferator-activated receptors by eicosanoids. Fournal of Biological Chemistry 270 23975-23983.

Zhang B, Marcus SL, Sajjadi FG, Alvares K, Reddy JK, Subramani S, Rachubinski RA \& Capone JP 1992 Identification of a peroxisome proliferator-responsive element upstream of the gene encoding rat peroxisomal enoyl-CoA hydratase/3-hydroxyacyl-CoA dehydrogenase. Proceedings of the National Academy of Sciences of the USA $897541-7545$.

RECEIVED 5 June 1998 